\title{
RELAXED CONTROL OF NUCLEIC ACID SYNTHESIS BY A MUTANT OF PSEUDOMONAS
}

\author{
YAO-TUNG LIU ${ }^{1}$, HAJIME TAKAHASHI ${ }^{2}$ AND BUNJI MARUO* \\ Laboratory of Radiation Genetics, Faculty of Agriculture, University of Tokyo, \\ and
}

The Institute of Applied Microbiology, University of Tokyo, Bunkyo-ku, Tokyo

(Received February 15, 1968)

\begin{abstract}
Synthetic activities of macromolecules by temperature-sensitive mutants of Pseudomonas-P were examined at elevated temperatures. One of the strains, Tm-7, exhibited unusually high synthetic activities of protein and nucleic acids under such conditions. Nucleic acid synthesis of this strain continued even in the absence of histidine, which is an amino acid required for growth. No appreciable protein synthesis occurred under these conditions. Analysis of nucleic acids synthesized in a histidine-free medium revealed that radioactive phosphate was incorporated into DNA, soluble and ribosomal RNAs, as well as into other heterogeneous RNAs. The synthesized RNAs were highly susceptible to enzymatic hydrolysis. The relaxed control of nucleic acid synthesis, however, appears to be unrelated to the temperature sensitivity.
\end{abstract}

It was first described in 1955 by BOREK et al. (1) that a methionine-less strain of Escherichia coli K12 W-6 (or 58-161) continued to synthesize RNA for a certain period of time in a methionine-free medium. This strain was the subject of studies of STENT and BRENNER (2), and of ALFOLDI et al. (3) on the control mechanism of RNA synthesis. They designated the mutant allele of the RNA control gene which apparently permits the RNA synthesis under the amino acid deficiency as the "relaxed control" ( $\left.\mathrm{RC}^{\mathrm{rel}}\right)$, and the normal allele as the "stringent control" $\left(\mathrm{RC}^{\mathrm{st}}\right)$. Up to the present, all other known $\mathrm{RC}^{\mathrm{rel}}$ strains are related to $\mathrm{K} 12 \mathrm{~W}-6$. The synthesized RNA species accumulated by these strains in the absence of a particular amino acid, which is required for growth, appear to consist of ribosomal (23 S and $16 \mathrm{~S}$ ) and soluble RNAs (4S). The occurrence of RNAs which stimulate polypeptide synthesis in vitro is also known to be formed under these conditions $(4,5)$.

Through the examination of RNA synthesis of temperature-sensitive

1 Present Address: Taiwan Sugar Experiment Station, Tainan, Taiwan, China.

2 Present Address: Department of Agricultural Chemistry, Faculty of Agriculture, Tohoku University, Sendai. 
mutants of Pseudomonas-P, a mutant having a nature of an RNA relaxed control was obtained. This mutant, which grows normally at low temperatures $\left(25-27^{\circ}\right)$ but forms no colony at elevated temperatures $\left(35-37^{\circ}\right)$, was isolated by the method previously described (6). A tracer experiment confirmed that this strain synthesizes RNA under conditions which do not support a net protein synthesis. This paper deals with the synthetic activities of the temperature-sensitive mutant and some properties of the synthesized RNAs under the amino acid deficiency.

\section{MATERIALS AND METHODS}

Strains and cultural conditions. The temperature-sensitive mutants were derived from the parental strain $\left(\mathrm{H}^{-} \mathrm{U}^{-}-6\right)$, which required histidine and uracil for growth, by the glycine-penicillin screening method $(6)$. The $\mathrm{H}^{-} \mathrm{U}^{-}-6$ strain was derived from the wild strain of Pseudomonas-P, which was originally isolated by MARUYAMA and NOMURA (7). These bacteria were maintained in a bouillon-yeast extract medium (BY, $\mathrm{pH} 7.0$ ) which contained $1 \%$ meat extract (Kyokuto Seiyaku), 1\% Polypeptone (Daigo Eiyo), 0.5\% yeast extract (Difco), and $0.2 \%$ sodium chloride. For the solid medium, agar (1.7\%) was added. This medium was also used for the examination of temperature sensitivity. The diluted medium $(1 / 20)$ was employed for some radioisotope incorporation experiments.

A synthetic medium containing $17 \mathrm{~L}$-amino acids $(200 \mu \mathrm{g} / \mathrm{ml}$ each $), 0.2 \%$ glucose, $0.01 \%$ uracil and salt solutions $\mathrm{A}$ and $\mathrm{B}$ was used for seed cultures. The 17 amino acids were alanine, aspartic acid, arginine, glycine, glutamic acid, histidine, isoleucine, leucine, lysine, methionine, phenylalanine, proline, serine, threonine, tryptophan, tyrosine, and valine. The salt solutions $\mathrm{A}$ and $\mathrm{B}$, ten times concentrated, contained the following ingredients per liter of water. (A) $2.94 \mathrm{~g}$ of sodium citrate $\left(\mathrm{C}_{6} \mathrm{H}_{5} \mathrm{O}_{7} \mathrm{Na}_{3} \cdot 2 \mathrm{H}_{2} \mathrm{O}\right), 54 \mathrm{~g}$ of $\mathrm{NaCl}, 30 \mathrm{~g}$ of $\mathrm{KCl}, 4.06 \mathrm{~g}$ of $\mathrm{MgCl}_{2} \cdot 6 \mathrm{H}_{2} \mathrm{O}, 0.396 \mathrm{~g}$ of $\mathrm{MnCl}_{2} \cdot 4 \mathrm{H}_{2} \mathrm{O}, 0.27 \mathrm{~g}$ of $\mathrm{FeCl}_{3} \cdot 6 \mathrm{H}_{2} \mathrm{O}$, and $0.147 \mathrm{~g}$ of $\mathrm{CaCl}_{2} \cdot 2 \mathrm{H}_{2} \mathrm{O}$. (B) $78.5 \mathrm{~g}$ of $\mathrm{K}_{2} \mathrm{HPO}_{4}, 26.4 \mathrm{~g}$ of $\mathrm{KH}_{2} \mathrm{PO}_{4}$, and $45.4 \mathrm{~g}$ of $\mathrm{Na}_{2} \mathrm{SO}_{4}$. For the main cultures and most of the radioisotope incorporation experiments, a synthetic medium was used. This medium contained the 17 amino acids $(40 \mu \mathrm{g} / \mathrm{ml}$ each), uracil $(20 \mu \mathrm{g} / \mathrm{ml})$, phosphate $(20 \mu \mathrm{g} / \mathrm{ml}$ as $\mathrm{P})$, sulfate $\left(10 \mu \mathrm{g} / \mathrm{ml}\right.$ as $\mathrm{S}$ ), and $10^{-2} \mathrm{M}$ Tris buffer (final, $\mathrm{pH} 7.4$ ). The other constituents, except those indicated above, were the same as the seed medium.

A loopful of cells from a fresh slant was transferred to the seed medium and, after shaking at $25-27^{\circ}$ for $16 \mathrm{hr}$, a $5 \%$ inoculum was poured into the main culture medium. The culture was continued for additional $2 \mathrm{hr}$. At this stage, optical density of the culture usually reached $0.6(550 \mathrm{~m} / \mu)$ and corresponded to the early log phase. Cells were centrifuged, washed, and resuspended in the incorporation medium. The necessary additions were made at zero time, and the mixture was incubated for $90 \mathrm{~min}$ with shaking at $37^{\circ}$.

Preparation and analyses of nucleic acids. The cells, which were washed 
once with a Tris-Mg buffer $\left(5 \times 10^{-2} \mathrm{M}\right.$ Tris buffer containing $5 \times 10^{-3} \mathrm{M} \mathrm{MgCl}_{2}$, $\mathrm{pH} 7.5$ ), were ground with silica sand in the cold. Nucleic acids were extracted with an equal volume of $90 \%$ phenol in the presence of $0.2 \%$ sodium dodecyl sulfate. After centrifugation, $2 \%$ of potassium acetate and two volumes of cold ethanol $\left(-20^{\circ}\right)$ were added to the aqueous phase. The tube was placed in the cold for several $\mathrm{hr}$. The nucleic acid precipitate was collected and dissolved in 1 to $2 \mathrm{ml}$ of the Tris- $\mathrm{Mg}$ buffer and dialyzed against the same buffer.

Fractionation of nucleic acids with a methylated albumin-kieselguhr (MAK) column chromatography was carried out according to the method of LERMAN (8). The sucrose density gradient $(3-20 \%)$ analysis of the nucleic acids was performed with a Hitachi SW-40 rotar at $40,000 \mathrm{rpm}$ for $210 \mathrm{~min}$. The nucleic acid samples were treated with DNase $(10 \mu \mathrm{g} / \mathrm{ml}$, Worthington, beef pancreas, $1 \times$ crystallized) in $10^{-2} \mathrm{M}$ Tris buffer containing $2 \times 10^{-3} \mathrm{M} \mathrm{MgCl}_{2}$ for $30 \mathrm{~min}$ in an ice bath prior to centrifugation. After the spinning, the tube was punctured at the bottom, and every 10 drops were collected. Each fraction was diluted with $3 \mathrm{ml}$ of the Tris- $\mathrm{Mg}$ buffer, and the radioactivity and the absorbancy at $260 \mathrm{~m} \varphi$ were determined.

Other analytical methods. The optical density of the culture was usually measured by a Beckman DU spectrophotometer at $550 \mathrm{~m} \mu$ after appropriate dilution with water. In some experiments, optical density of the culture was directly recorded with a photometer equipped with a 660 filter and was expressed as arbitrary (ADS) units. These two values are proportional to cell mass.

Fractionation of the cells was carried out by the Schmidt-ThannhauserSchneider (STS) method (9). Fractionation of polyphosphate and RNA was carried out according to the method of KADOWAKI et al. (10). Radioactivity was usually assayed by an automatic G-M counter (Nihon Musen). ${ }^{32} \mathrm{P}$ and ${ }^{35} \mathrm{~S}$ in the double tracer experiments were counted by a Packard Tri-Carb liquid scintillation spectrometer.

\section{RESULTS}

\section{Change in optical density of the culture in BY medium at $35^{\circ}$}

The temperature-sensitive mutants ( $\mathrm{Tm}^{\mathrm{s}}-115,-117$ and -121 ) and their parental strain $\left(\mathrm{H}^{-} \mathrm{U}^{-}-6\right)$ were grown in the BY medium at $25^{\circ}$. When the early $\log$ phase was reached, the temperature of the culture was increased to $35^{\circ}$. The change in optical density after the temperature shift is recorded in Fig. 1. No increase in the optical density was observed with $\mathrm{Tm}^{\mathrm{s}}-115$ during the incubation. On the contrary, the increase in the optical density of $\mathrm{Tm}^{\mathrm{s}}-117$ paralleled that of the parental strain up to $30 \mathrm{~min}$, but leveled off gradually by a longer incubation. A similar increase in the optical density was observed with $\mathrm{Tm}^{3}-7$, as will be shown later. With $\mathrm{Tm}^{-121}$, the optical density decreased considerably during the initial $30 \mathrm{~min}$, but increased thereafter. Thus, it might be said that the synthetic activities of these mutants 


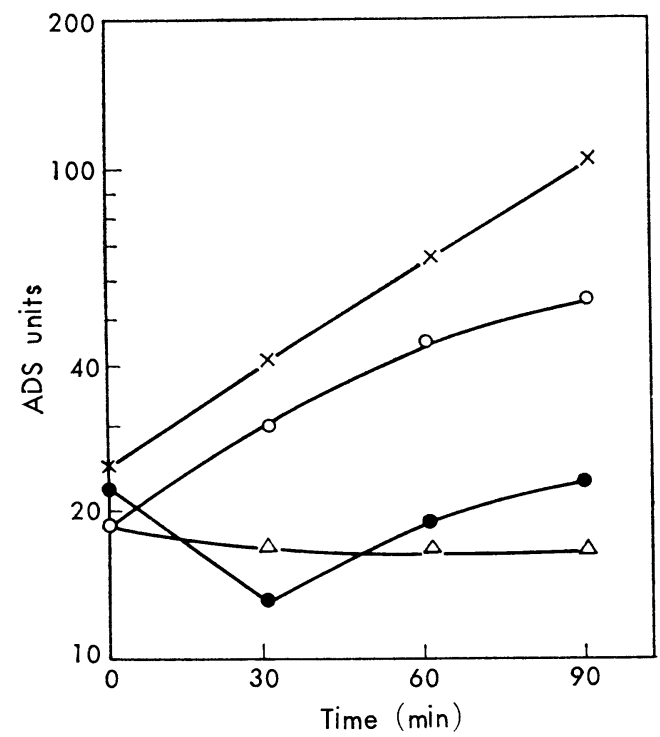

Fig. 1. Optical density changes of cultures of temperaturesensitive mutants at $35^{\circ}$.

The log phase cultures in the BY medium at $25^{\circ}$ were transferred to $35^{\circ}$ at zero time.

$$
\begin{array}{llll}
\times-\times & \mathrm{H}^{-} \mathrm{U}^{-}-6 & \bigcirc-\bigcirc & \mathrm{Tm}^{\mathrm{s}}-117 \\
-\bullet & \mathrm{Tm}^{\mathrm{s}-121} & \triangle-\triangle & \mathrm{Tm}^{\mathrm{s}-115}
\end{array}
$$

vary to a considerable extent depending on their nature.

Temperature-sensitive mutants with abnormal activity of nucleic acid synthesis

The nucleic acid and protein syntheses of temperature-sensitive mutants as well as their parental strain were examined with the aid of ${ }^{32} \mathrm{P}$ and ${ }^{35} \mathrm{~S}$ double tracer experiments. The cells at the early log phase in the BY medium at $27^{\circ}$ were washed twice with Tris buffer and resuspended in the diluted BY medium $(1 / 20)$. ${ }^{32} \mathrm{P}$-Orthophosphate (carrier free, $0.025 \mu \mathrm{Ci} / \mathrm{ml}$ ) and ${ }^{35} \mathrm{~S}$-sulfate (carrier-free, $0.5 \mu \mathrm{Ci} / \mathrm{ml}$ ) were added to this medium and, after $30-\mathrm{min}$ incubation at $27^{\circ}$ or $37^{\circ}$, the cells were fractionated. The radioactivities of ${ }^{32} \mathrm{P}$ and ${ }^{35} \mathrm{~S}$ in the acid-insoluble fractions are shown in Table 1 . The synthetic activities of nucleic acid and protein of the strains $\mathrm{Tm}^{\mathrm{s}}-115$ and -108 decreased markedly at $37^{\circ}$. The $\mathrm{Tm}^{\mathrm{s}}-121$ showed no appreciable difference in protein synthesis but the nucleic acid synthesis decreased considerably at higher temperature. The reverse was the case with $\mathrm{Tm}^{\mathrm{s}}-103$ and -117 in which protein synthesis was inhibited at $37^{\circ}$. The abnormally high synthetic activities of nucleic acid and protein were manifested by the $\mathrm{Tm}^{\mathrm{s}}-7$ at $37^{\circ}$. 
Table 1. Syntheses of nucleic acids and protein by temperature-sensitive mutants at $27^{\circ}$ and $37^{\circ}$.

\begin{tabular}{|c|c|c|c|c|}
\hline \multirow{3}{*}{ Strain } & \multicolumn{4}{|c|}{$\begin{array}{l}\text { Total radioactivity in acid-insoluble fraction } \\
\qquad(\mathrm{cpm})\end{array}$} \\
\hline & \multicolumn{2}{|c|}{${ }^{32} \mathrm{P}$} & \multicolumn{2}{|c|}{${ }^{35} \mathrm{~S}$} \\
\hline & $37^{\circ}$ & $27^{\circ}$ & $37^{\circ}$ & $27^{\circ}$ \\
\hline $\mathrm{H}^{-} \mathrm{U}^{-}-6$ & 2750 & 2910 & 460 & 640 \\
\hline $\operatorname{Tm}^{\mathrm{s}}-7$ & 2860 & 2690 & 520 & 480 \\
\hline$T m^{s-103}$ & 4650 & 4470 & 670 & 1270 \\
\hline$T m^{s-108}$ & 340 & 890 & 60 & 260 \\
\hline $\mathrm{Tm}^{\mathrm{s}-115}$ & 230 & 710 & 70 & 160 \\
\hline $\operatorname{Tm}^{\mathrm{s}}-117$ & 710 & 660 & 160 & 200 \\
\hline $\mathrm{Tm}^{\mathrm{s}}-121$ & 110 & 480 & 80 & 80 \\
\hline
\end{tabular}

To the reaction mixture $(4.5 \mathrm{ml}$ each) incubated for $30 \mathrm{~min}, 0.5 \mathrm{ml}$ of cold $40 \%$ trichloroacetic acid was added. The mixture was kept in an ice bath for $30 \mathrm{~min}$. After the precipitate was washed once with ethanol-ether, the residue was dissolved in $1 \mathrm{ml}$ of $1 \mathrm{~N} \mathrm{NH}_{4} \mathrm{OH}$ at $50^{\circ}$ for $10 \mathrm{~min}$. The solution was centrifuged and the supernatant $(0.5 \mathrm{ml})$ was assayed for ${ }^{32} \mathrm{P}$ and ${ }^{35} \mathrm{~S}$. Thus, ${ }^{32} \mathrm{P}$ and ${ }^{35} \mathrm{~S}$ radioactivities represent mostly nucleic acids and protein syntheses, respectively.

The temperature sensitivity of the $\mathrm{Tm}^{\mathrm{s}}-7$ was reinvestigated in view of its abnormally high activities at elevated temperatures. However, no revertant, which can grow at $37^{\circ}$, was found among the tested colonies indicating that the strain was really temperature sensitive. The nutritional requirements were then re-examined and the strain was found to require histidine, uracil and arginine for growth. This observation is consistent with the fact that this strain was derived from the $\mathrm{H}^{-} \mathrm{U}^{-}-6$ parent.

\section{Nucleic acid synthesis of $\mathrm{Tm}^{s}-7$ in deficient media}

The washed cells in the early log phase were transferred to the incorporation media containing ${ }^{32} \mathrm{P}$-orthophosphate from which various nutrients were deleted. After a 30 -min incubation at $27^{\circ}$ or $37^{\circ}$, the cells were collected and fractionated by the STS method. The results shown in Table 2 indicate that the deletion of all the 17 amino acids from the medium results in a considerable inhibition of nucleic acid synthesis but the single deletion of either uracil, glucose, histidine, or magnesium ion from the incorporation medium leads to the inhibition of ${ }^{32} \mathrm{P}$ incorporation into RNA and DNA only to a small extent.

\section{Syntheses of macromolecules by $\mathrm{Tm}^{\mathrm{s}}-7$ in histidine-free media}

The washed cells of the early log phase were preincubated in the incorporation medium from which histidine was removed. After $30 \mathrm{~min}$ at $37^{\circ}$, the 
Table 2. RNA and DNA syntheses by strain $\mathrm{Tm}^{\mathrm{s}}-7$ in various media.

\begin{tabular}{|c|c|c|c|c|}
\hline \multirow{3}{*}{ Incubation medium } & \multicolumn{4}{|c|}{$\begin{array}{l}\text { Radioactivity } \\
\left(\mathrm{cpm} / \mathrm{OD}_{2 \in 0 \mathrm{~m} \mu}\right)\end{array}$} \\
\hline & \multicolumn{2}{|c|}{ RNA fraction } & \multicolumn{2}{|c|}{ DNA fraction } \\
\hline & $37^{\circ}$ & $27^{\circ}$ & $37^{\circ}$ & $27^{\circ}$ \\
\hline Complete & 6270 & 1810 & 10450 & 3340 \\
\hline Minus 17 amino acids & 1520 & 720 & 1480 & 810 \\
\hline Minus uracil & 5260 & 2420 & 9340 & 4140 \\
\hline Minus glucose & 7070 & 2870 & 10550 & 3320 \\
\hline Minus histidine & 5060 & 1910 & 8070 & 2870 \\
\hline Minus 16 amino acids* & 1490 & 820 & 1610 & 840 \\
\hline Minus $\mathrm{MgCl}_{2}$ & 5790 & 920 & 4790 & 950 \\
\hline
\end{tabular}

* Histidine was added as a sole amino acid.

medium was divided into two portions. One portion was added with $40 \mu \mathrm{g} / \mathrm{ml}$ of histidine and was used as the complete culture. Each culture was further divided into three portions. To two of them was added either ${ }^{14} \mathrm{C}$-DL-leucine

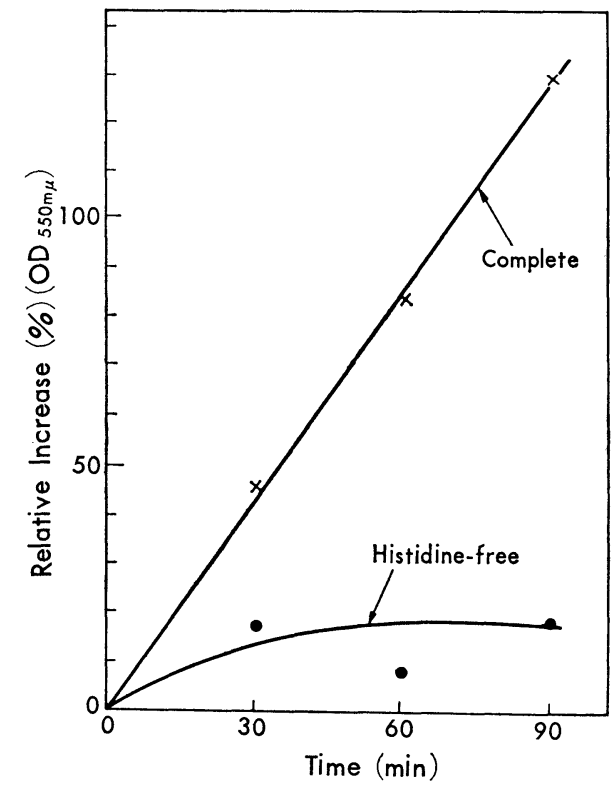

Fig. 2. Optical density changes of cultures of $\mathrm{Tm}^{\mathrm{s}}-7$ in complete and histidine-free media at $37^{\circ}$.

Initial optical density at $550 \mathrm{~m} \mu$ of cultures was 0.130 . 
$(1 \mu \mathrm{Ci} / \mathrm{ml}$, specific activity $3.5 \mathrm{mCi} / \mathrm{mM})$ or ${ }^{32} \mathrm{P}$-orthophosphate (carrier-free, $1 \mu \mathrm{Ci} / \mathrm{ml}$ ). The other portion was left untouched. All the tubes were incubated simultaneously at $37^{\circ}$. At time intervals, cells which incorporated ${ }^{14} \mathrm{C}$ were filtered on a membrane filter and washed with cold $5 \%$ trichloroacetic acid. The remaining radioactivity on the filter was counted. Cells were collected at intervals and fractionated by the STS method. Radioactivities of RNA, DNA, and polyphosphate fractions were measured. The change in the optical density during the incubation was followed with a medium $(7 \mathrm{ml})$ containing no radioisotope.

Fig. 2 shows that the increment in optical density during the incubation was inhibited greatly in the histidine-free medium. Almost linear increment was observed in the complete medium. The inhibition of ${ }^{14} \mathrm{C}$-leucine incorporation in the histidine-free medium (Fig. 3) was more marked than that of the optical density. The incorporation of ${ }^{32} \mathrm{P}$ into RNA fraction, however, was less affected by the absence of histidine as shown in Fig. 4. Fig. 5 shows the effect of histidine deletion on the incorporation of ${ }^{32} \mathrm{P}$ into the DNA fraction. DNA synthesis also continued in histidine deficiency. Fig. 6 shows the effect of histidine on the incorporation of ${ }^{32} \mathrm{P}$ into polyphosphate fraction. In this case, more abundant synthesis occurred under the histidine-free condition.

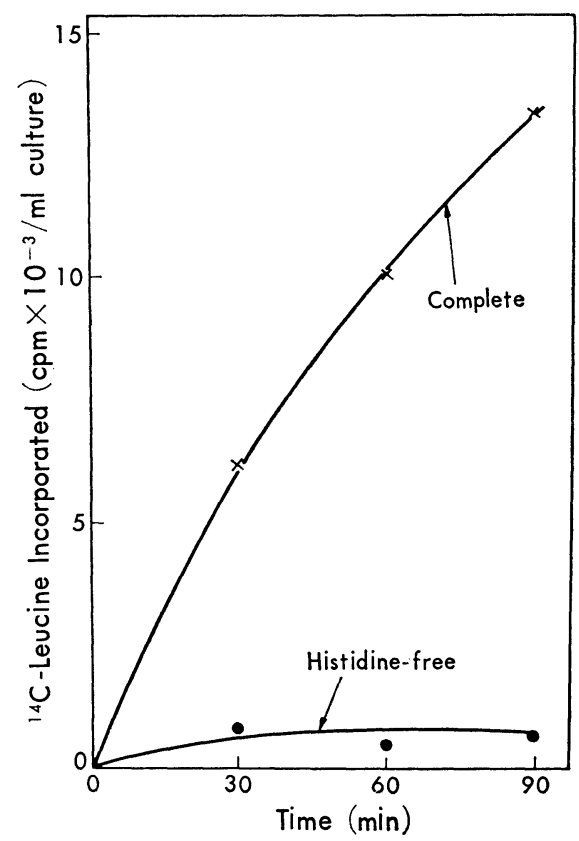

Fig. 3. Uptake of ${ }^{14} \mathrm{C}$-leucine into acid-insoluble fraction of $\mathrm{Tm}:-7$ in complete and histidine-free media at $37^{\circ}$. 


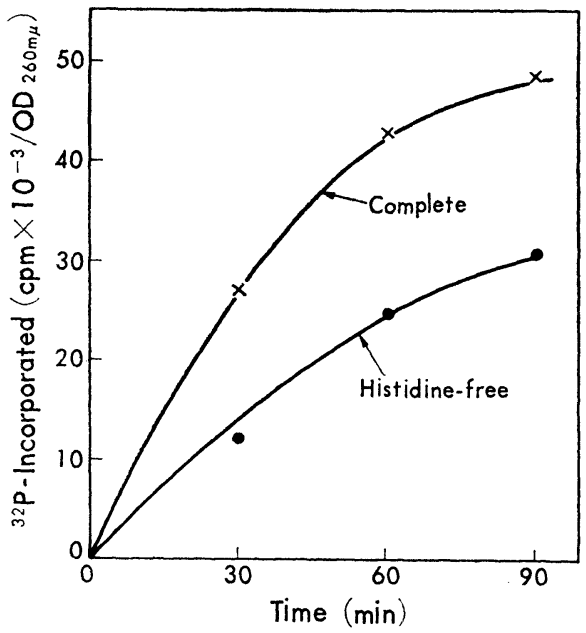

Fig. 4. Uptake of ${ }^{52} \mathrm{P}$ into RNA fraction of $\mathrm{Tm} \div-7$ in complete and histidine-free media at $37^{\circ}$.

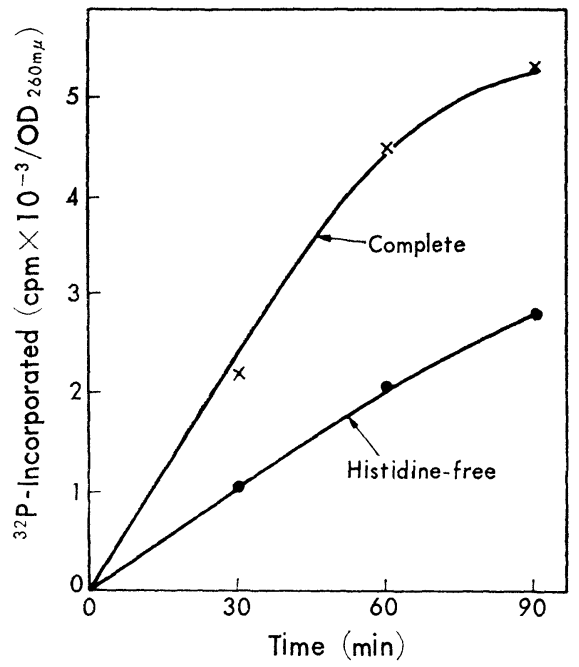

Fig. 5. Uptake of ${ }^{32} \mathrm{P}$ into DNA fraction of $\mathrm{Tm}^{\mathrm{s}}-7$ in complete and histidine-free media at $37^{\circ}$.

The increment of RNA and DNA as determined by spectrophotometry during the incubation is shown in Fig. 7. RNA and DNA synthesized in the histidine-free medium were approximately 18 and $25 \%$ of those in the complete medium, respectively (calculated from the data of $60-\mathrm{min}$ incubations). This 


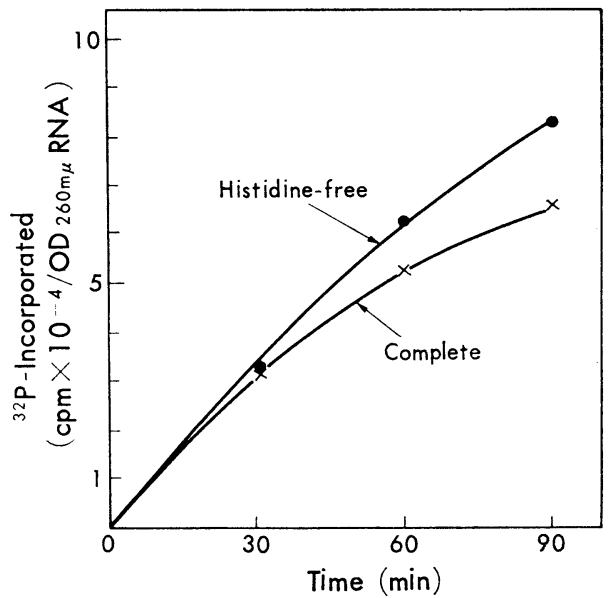

Fig. 6. Uptake of ${ }^{32} \mathrm{P}$ into polyphosphate fraction of $\mathrm{Tm} s-7$ in complete and histidine-free media at $37^{\circ}$

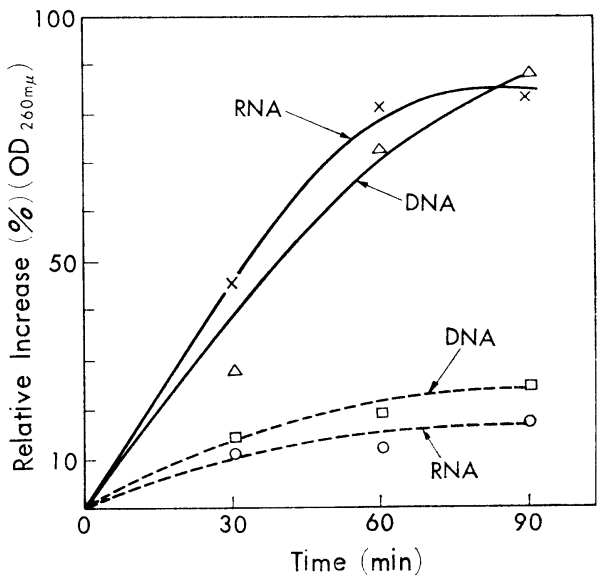

Fig. 7. Increase in the amounts of RNA and DNA of $\mathrm{Tm}-7$ in complete and histidine-free media at $37^{\circ}$.

The initial optical densities at $260 \mathrm{~m} \mu$ of $\mathrm{RNA}$ fractions ( $5 \mathrm{ml}$, each) of complete and histidine-free cultures were 1.64 and 1.56, respectively, and those of DNA fractions $(5 \mathrm{ml}$, each) of complete and histidinefree cultures were 0.292 and 0.298 , respectively.

___ Complete medium, .... Histidine-free medium 
is in contrast to the observation of the tracer experiments which showed that the rates of both nucleic acid syntheses were approximately $50 \%$ or more in the histidine-free medium as compared to the complete medium. These results suggest the occurrence of a turnover of nucleic acids under histidine deficiency.

\section{Some properties of RNA synthesized in histidine-free medium}

The nucleic acid fraction, prepared from the cells which were incubated with ${ }^{32} \mathrm{P}$-orthophosphate for $60 \mathrm{~min}$ under conditions similar to the preceding experiment, was analyzed by the MAK column and the sucrose density gradient centrifugation.

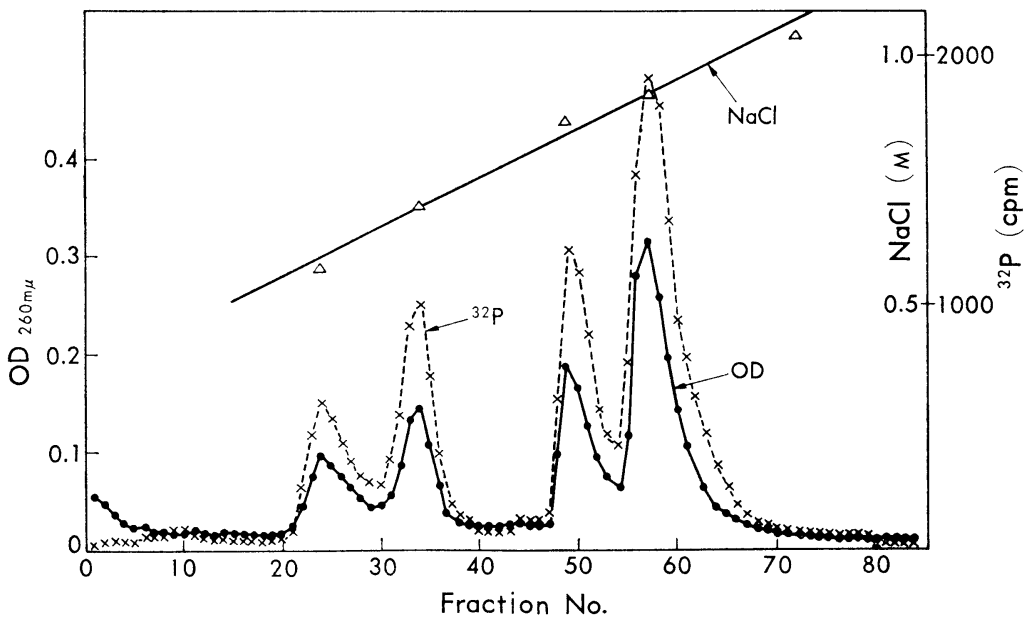

Fig. 8. MAK column chromatography of nucleic acid fraction of $\mathrm{Tm}^{\mathrm{s}-7}$ incubated in complete medium at $37^{\circ}$.

Fig. 8 shows the elution profile of nucleic acids by the MAK column obtained from the cells incubated in the complete medium. The radioactivity of each fraction exactly paralleled the absorbancy at $260 \mathrm{~m} \mu$. Fig. 9 shows the pattern of the centrifugation of the same nucleic acid sample. Again, the pattern of radioactivity paralleled that of absorbancy. However, the MAK analysis of the nucleic acids, obtained from the cells incubated in the histidinefree medium, showed a considerably different radioactivity profile from that of absorbancy (Fig. 10). Although the radioactivity was found in the regions corresponding to s-RNA (around the fraction 30), DNA (around the fraction 40 ), and possibly to two ribosomal RNAs (around fractions 57 and 65), various other heterogeneous nucleic acid species were detectable from the counting data. 


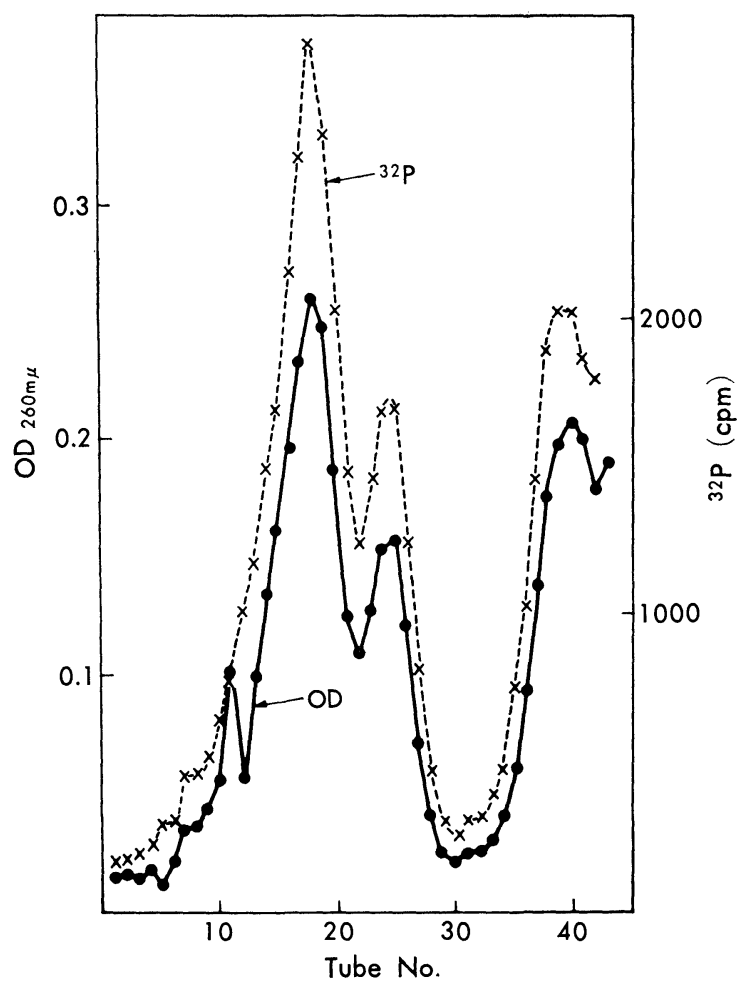

Fig. 9. Sucrose density gradient centrifugation analysis of nucleic acids of $\mathrm{Tm}^{\mathrm{s}-7}$ incubated in complete medium at $37^{\circ}$.

The density gradient analysis of nucleic acids from the histidine-free culture, shown in Fig. 11, indicates, however, that the profiles of radioactivity and absorbancy at $260 \mathrm{~m} \mu$ are completely different from the data of Fig. 9 . Two ribosomal RNAs, possibly corresponding to $16 \mathrm{~S}$ and $23 \mathrm{~S}$, disappeared and, instead, one broad peak appeared in the ribosomal RNA regions. It is also noteworthy that the larger amounts of small molecular nucleic acid species were observed under histidine-free conditions. The discrepancy, that the two ribosomal peaks were observed by the MAK analysis and only one appeared in the regions of ribosomal RNAs by the centrifugation both in radioactivity and absorbancy, might be attributed to the DNase pretreatment of the nucleic acid sample in the density gradient analysis. To elucidate the effect of the DNase treatment, the DNase-treated nucleic acid sample, which was obtained from the cells in the histidine-free culture, was chromatographed with the MAK column. The elution pattern is shown in Fig. 12. The regions of ribosomal RNAs (fractions around 70 and 80 ) behaved differently from the sample which was not treated by the DNase (Fig. 10). Like the observation 


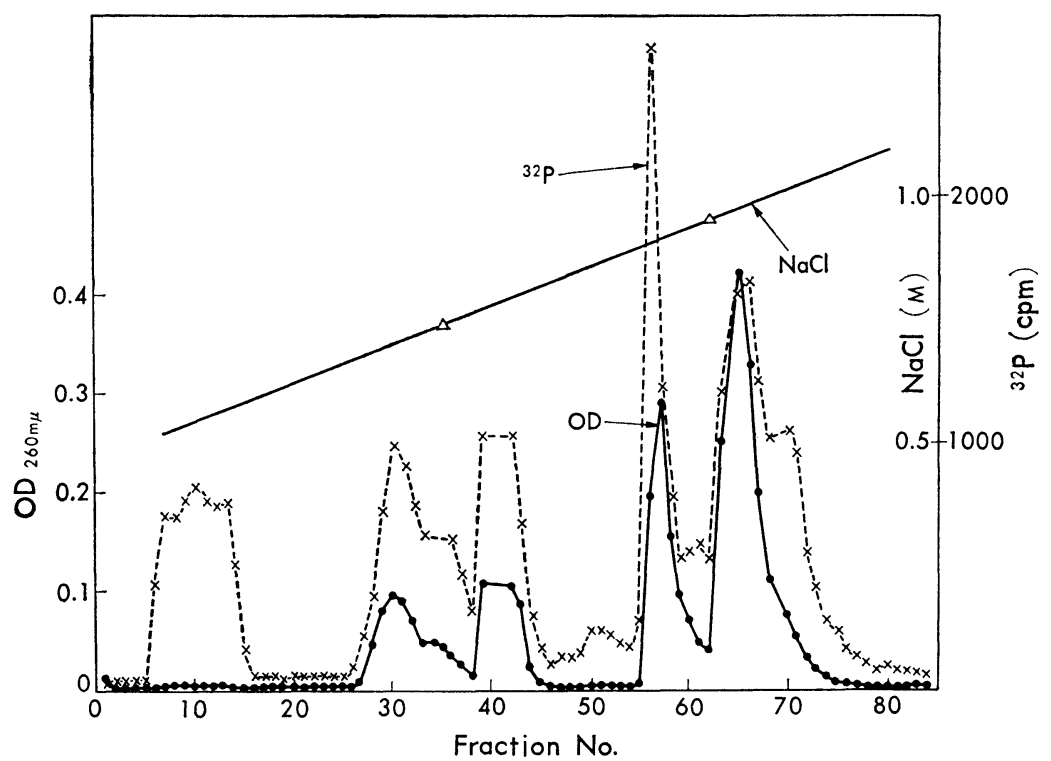

Fig. 10. MAK column chromatography of nucleic acids of $\mathrm{Tm}:-7$ incubated in histidine-free medium at $37^{\circ}$.

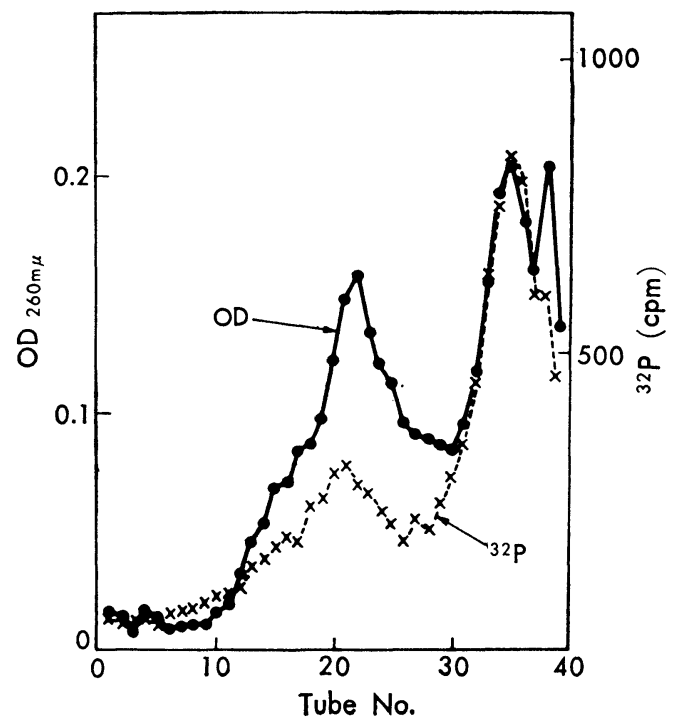

Fig. 11. Sucrose density gradient centrifugation analysis of nucleic acids of $\mathrm{Tm}^{\mathrm{s}}-7$ incubated in histidine-free medium at $37^{\circ}$. 


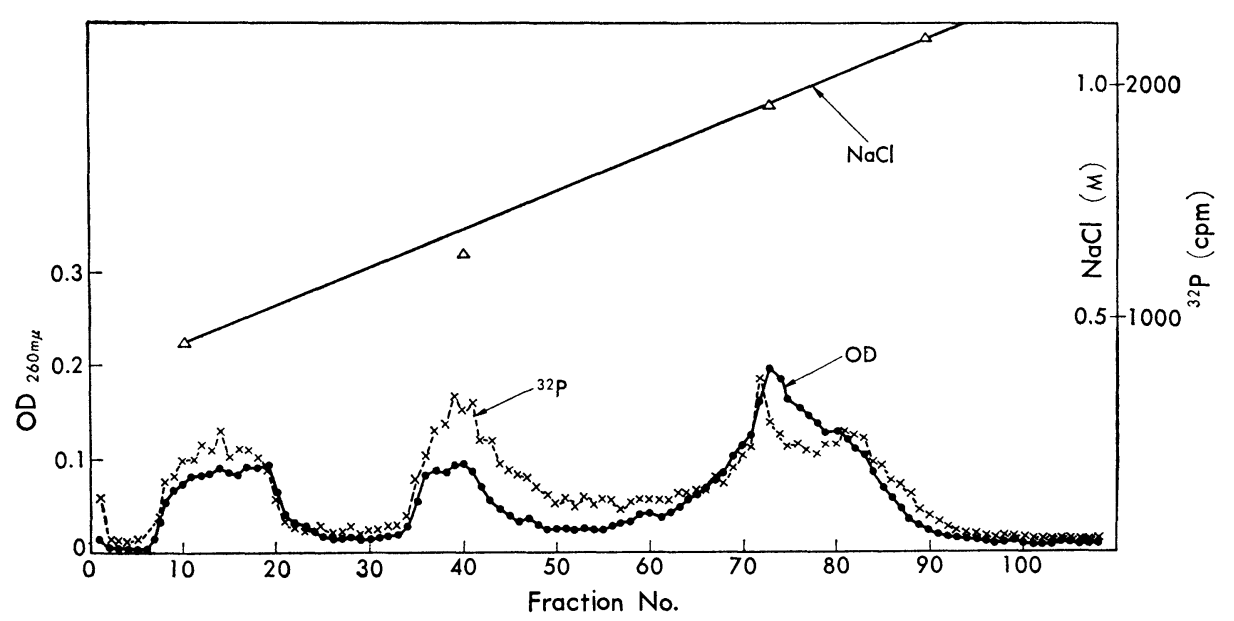

Fig. 12. MAK column chromatography of DNase-treated nucleic acids of $\mathrm{Tm}^{\mathrm{s}}-7$ incubated in histidine-free medium at $37^{\circ}$.

by the centrifugal analysis, the clear separation of two ribosomal RNAs could not be achieved by the chromatography of the DNase-treated sample. Since the clear separation of ribosomal RNAs was obtained by the centrifugal analysis of the DNase-treated nucleic acid sample obtained from the cells in the complete medium, the DNase effect appears to be specific for nucleic acids synthesized and/or degraded in the cells which were incubated in the histidine-free medium. In confirmation of this view, the nucleic acid preparation obtained from the cells, which were cultured in the complete medium, was analyzed by the MAK column after the DNase pretreatment. As shown in Fig. 13, no detectable DNA was found in the elution profile, but the clear separation of s-RNA (fractions around 40) and two ribosomal RNAs (fractions from 71 to 91 ) was observed.

The foregoing experiments could be explained if the mutant synthesizes various species of DNA, which migrate to the region of ribosomal RNAs in the MAK chromatography, under histidine-free conditions. Thus, the valid RNA analysis is only feasible after a DNase treatment. This view, however, is not supported, since the nucleic acid preparation obtained from the cells, which were incubated in the histidine-free medium, gave only two peaks in the MAK analysis after the treatment with RNase $(20 \mu \mathrm{g} / \mathrm{ml}$, Sigma, bovine pancreas, crystallized 5 times, incubated for $30 \mathrm{~min}$ at $37^{\circ}$ ) as shown in Fig. 14. Obviously, the peak around tube number 43 is DNA and the other peak around tube number 10 is presumably the degradation products of RNA by enzymatic hydrolysis. Therefore, it is apparent that the RNA accumulated under histidine-free conditions, especially the species migrating to the ribosomal RNAs in the MAK and centrifugal analyses and which constitute the major 


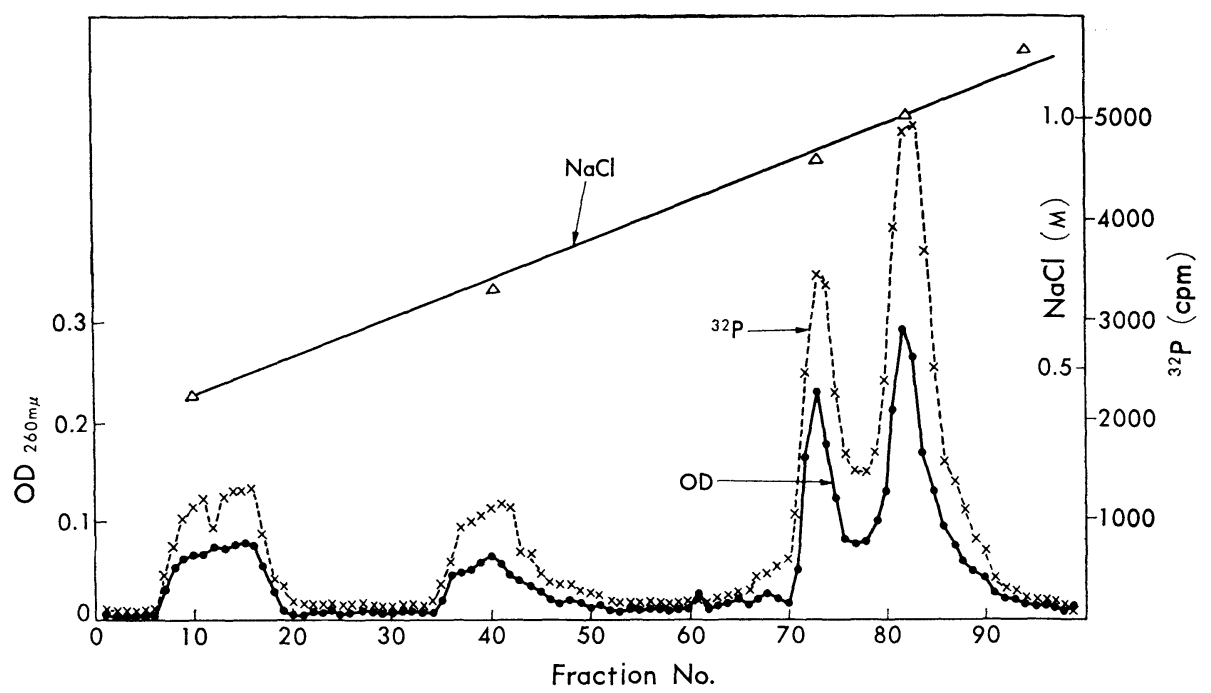

Fig. 13. MAK column chromatography of DNase-treated nucleic acids of $\mathrm{Tm}^{\mathrm{s}}-7$ incubated in complete medium at $37^{\circ}$.

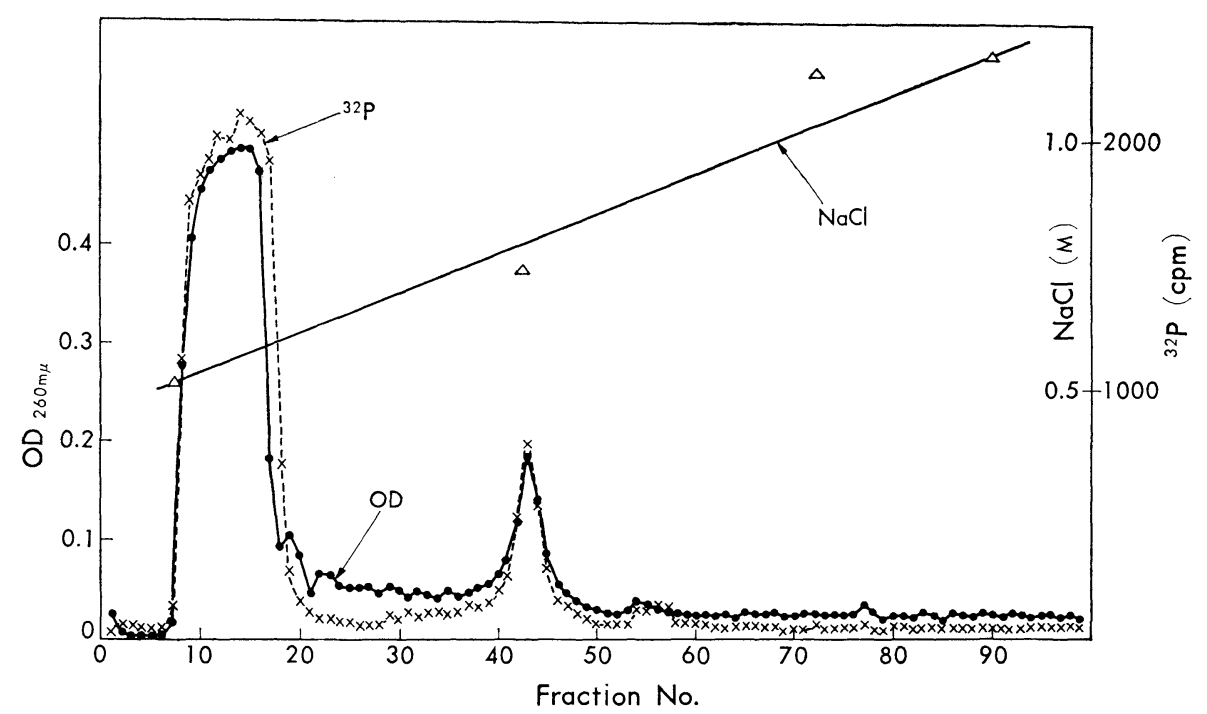

Fig. 14. MAK column chromatography of RNase-treated nucleic acids of $\mathrm{Tm}$ s-7 in histidine-free medium at $37^{\circ}$.

portion of RNA synthesized, has an unusual property in that it is seemingly sensitive to the DNase preparation used in this experiment. 


\section{DISCUSSION}

The present experiment demonstrated that some temperature-sensitive mutants of Pseudomonas continued to synthesize macromolecules at elevated temperatures which did not permit their colony formation on the agar plates. Among these mutants, the $\mathrm{Tm}^{\mathrm{s}}-7$ was selected for further investigation because of its unusual high activities of RNA and protein syntheses at $37^{\circ}$.

This mutant synthesizes nucleic acids even in the absence of histidine which is one of the required amino acids for this organism. The deletion of 16 other amino acids markedly inhibited the nucleic acid synthesis as shown in Table 2, suggesting their potential role as energy sources and/or precursors. The addition of glucose and uracil to the incubation medium instead of amino acids, however, failed to restore synthetic activities.

The deletion of histidine from the incorporation medium resulted in the almost complete inhibition of protein synthesis (Fig. 3), but in the partial inhibition (approximately 50\%) of RNA and DNA syntheses (Figs. 4 and 5). The larger degree of inhibition of nucleic acid synthesis in the absence of histidine, as compared to the data in Table 2 , is attributable to preincubation in the histidine-free medium.

The increases of RNA and DNA as determined by spectrophotometry during incubation in the histidine-free medium were approximately 18 and $25 \%$, respectively, of those in the complete medium. Much lower values than those obtained by the tracer experiment strongly suggest the existence of a turnover of these nucleic acids in the absence of histidine. Probably, RNA and DNA initially present were degraded during the incubation and the resulting decomposition products were utilized for the synthesis of newly formed nucleic acids.

The chemical nature of RNA synthesized in the absence of histidine is worth noting. The RNA synthesized under such conditions was heterogeneous in nature as revealed by the MAK column chromatography (Fig. 10). The elution profile of radioactivity in the ribosomal RNA region, shown in Fig. 10, resembled that of the labeled RNA synthesized by the subcellular preparations from Pseudomonas-P (11). The material synthesized in vitro was shown to contain messenger RNAs (11). The finding that the RNAs synthesized and/or degraded during incubation in the histidine-free medium were hydrolyzed by DNase, as shown in Figs. 11 and 12, suggests the contamination of RNase in the enzyme preparation. Since the RNAs synthesized in the complete medium were resistant to the DNase, as shown in Figs. 9 and 13, it might be concluded that RNAs synthesized and/or degraded during incubation in the histidine-free medium are highly susceptible to RNase.

Although the present study demonstrated the relaxed control of nucleic acid synthesis in the temperature-sensitive mutant of Pseudomonas, the behavior appears to be unrelated to temperature sensitivity. As was shown in Table 2, the syntheses of RNA and DNA in the histidine-free medium also 
occurred at $27^{\circ}$.

The authors are grateful to Dr. Hikoyuki Yamaguchi and Dr. Shigeki Mizuno of the Laboratory of Radiation Genetics, Faculty of Agriculture, University of Tokyo, and to Dr. Isao Shibuya of The Institute of Applied Microbiology, University of Tokyo, for their advice and stimulating discussions. This investigation was supported in part by grants from the Waksman Foundation in Japan (to H. T.) and the National Council of Science Development, Republic of China (to Y. T. L.).

\section{REFERENCES}

1) E. Borek, A. Ryan and J. Rockenbach, J. Bacteriol., 69, 460 (1955).

2) G. S. Stent and S. Brenner, Proc. Natl. Acad. Sci. U.S., 47, 2005 (1961).

3) L. Alfoldi, G. S. Stent, M. Hoogs and B. Hill, Z. Vererbungslehre, 94, 285 (1963).

4) S. Dagley, A. E. White, D. G. Wild and J. Sykes, Nature, 194, 25 (1962).

5) L. R. MANDEL and E. BoREK, Biochemistry, 2, 560 (1963).

6) Y. T. Liu, H. Takahashi and B. Maruo, J. Gen. Appl. Microbiol., 13, 205 (1967).

7) Y. Maruyama and M. Nomura, J. Biochem., 43, 327 (1956).

8) L. S. Lerman, Biochim. Biophys. Acta, 18, 132 (1955).

9) I. Leslie, In The Nucleic Acids, ed. by E. Chargaff and J. N. Davidson, Vol. II, Academic Press, Inc., N. Y., (1955), p. 7.

10) K. Kadowaki, J. Hosoda and B. Maruo, Biochim. Biophys. Acta, 103, 311 (1965).

11) S. Mizuno, Doctorate Thesis, Agr. Sci., Univ. of Tokyo (1964). 